Running Head: MOODLE USAGE CASE STUDY

Moodle Usage Case Study at a University

\author{
Darrin Thomas \\ Faculty of Arts and Humanities \\ Asia-Pacific International University \\ Saraburi, Thailand \\ Dtsac18803@gmail.com
}


Running Head: MOODLE USAGE CASE STUDY

\section{Moodle Usage Case Study at a University}

ABSTRACT: the purpose of this study was to describe Moodle usage as Asia-Pacific International University (APIU). The results indicated that Moodle use is limited primarily to two activities (quizzes and assignments), the current memory needs meet the requirements of Moodle, and that there is a cyclical pattern to Moodle use at APIU. Lastly, Moodle use is generally low when considering memory requirements and or the proportion of activity and number of users.

Keywords: Moodle, e-learning, Thailand 
Running Head: MOODLE USAGE CASE STUDY

\section{Introduction}

The use of e-learning in tertiary education is almost ubiquitous. Universities and colleges are adopting various platforms to manage the-e-learning experience of their students, such as Moodle, Desire 2 Learn, Angel, and Blackboard among other choices (Edutechnica, 2014). This indicates that e-learning support is quickly becoming standard practice. However, the rapid adoption of learning management systems leads to unique challenges in a developing nation such as Thailand.

Thailand has an e-learning industry that is nearly non-existent (Saengpassa, 2013). This lack of an e-learning environment is evident despite huge growth in e-learning in Asia in general (Docebo, 2014). The barriers to implementation of e-learning include infrastructure, technology acceptance of faculty and students, and administrative support (Vicheanpanya, 2014)

In rural areas of Thailand, internet penetration is at less than $40 \%$ (Mala, 2016). This implies that a tertiary school in a rural setting could face challenges with embracing e-learning technology while being located outside of a major urban center. Therefore, it is critical to understand the currents use and potential future demand of the use of a learning management system in order to take the necessary steps to support e-learning at a tertiary school. This applies particularly to Asia-Pacific International University (APIU), as it is located in a part of Thailand that is experiencing rapid development but is still considered a rural setting.

Therefore, the purpose of this study is to assess the use of Moodle at Asia-PacificInternational University. The general objectives of this study are as follows

1. To assess activity rate of Moodle use over various measure of time.

2. To assess the user rate of Moodle at Asia-Pacific International university over various measures of time. 
Running Head: MOODLE USAGE CASE STUDY

Addressing these objectives will provide the administration team as a well as the Information Technology department with valuable information that can be used to develop strategic plans in relation to the continued inclusion of Moodle in the learning experience of students. Furthermore, institutions in a similar context will be able to compare their own use to that of an institution with similar characteristics.

\section{E-Learning}

E-learning is the continual use of technology with the purpose of teaching and learning (Huang \& Peng, 2011). Another definition of e-learning sees it as learning experiences that involves digital technology and the use of the internet (Peters, 2014). The experience of elearning can take one of several forms among them are fully-online and blended learning.

Fully-online learning is the traditional view of the use of e-learning. In this paradigm, learning only takes place through computers with no in-person contact between students and or with the teacher. The most obvious advantage of this is the flexibility it provides students with in their learning (Gaya, 2013). However, the flexibility can also lead to amotivation due to the lack of structure in addition to any technological limitations of the student (Gaya, 2013).4

Blended learning is a combination of online learning and traditional learning (Staker \& Horn, 2012). Blended learning has most of the same pros and cons as full online learning and includes the advantages of flexibility with the disadvantages of amotivation and technological challenges (Gogos, 2014; Pappas, 2015; Winstead, 2016). One unique problem many teachers face with blended learning is finding a proper balance between in class and online learning experiences (Bruff, Fisher, McEwen, \& Smith, 2013; Winstead, 2016). 
Running Head: MOODLE USAGE CASE STUDY

Blended learning has been found to be superior in terms of learning when compared to traditional face-to-face teach and even to fully-online learning experiences (Al-Qahtani \& Higgins, 2012; Means, Toyama, Murphy, \& Baki, 2013). Computer or technological support and some form of interaction between students and or with the teacher are also important in a blended learning context (Bernard, Borokhovski, Schmid, Tamim, \& Abrami, 2014).

Furthermore, learners involved in a blended learning environment developed autonomous learning skills through their engagement in this style of learning as they need to partial regulate their learning (Borich, 2012).

\section{Learning Management Systems}

The context in which fully online or blended learning takes place for most institutions is through a learning management system (LMS). The LMS provides an integrated platform to administrate, track, report and train individuals (Ellis, 2008). Academic institutions are the second largest user of LMS at $21 \%$ with corporations being number one (Capterra, 2015).

There are two forms in which LMS are available and these are closed and open. Closed LMSs are LMSs that need to be paid for. Examples include Desire2Learn, Canvas, and Blackboard. These three LMSs account for almost $60 \%$ of the tertiary education market and the average school that uses one of these LMSs has about 7000 students (Edutechnica, 2015).

Open LMSs are ones that are readily available for free. Moodle (modular object-oriented dynamic learning environment) is the strongest open LMS with a market share of $20 \%$ for tertiary institutions (Edutechnica, 2015). Moodle's market share surpasses Blackboard at schools with fewer than 2500 users, which indicates that Moodle may be more acceptable for use at small institutions (Edutechnica, 2014). 
Running Head: MOODLE USAGE CASE STUDY

For a small rural tertiary school, the cost of a closed LMS can be prohibitive. The average cost of a closed LMS per year at a tertiary school is about $\$ 70,000$ (Capterra, 2015). For a school that has $501-1500$ students the average price drops to $\$ 32,000$ dollars (Capterra, 2015). Most schools indicated that they spent more money than they planned on their (Capterra, 2015). Despite the issues with cost, it is not the main impetus for changing LMSs if switching takes place. The primary reasons for switching LMSs were ease of use and lack of support (Capterra, 2015; Stantchev, Colomo-Palacios, Soto-Acosta, \& Misra, 2014). As such, options such as Moodle, which is free, will continue to be an attractive alternative for many small universities.

\section{E-Learning in Thailand}

Asia has one of the fastest growth rates for e-learning at almost $20 \%$ annually (Docebo, 2014). However, in Thailand, less than ten institution offer online learning programs (Saengpassa, 2013). There is a negative perception of e-learning tools and a negative stigma towards the e-learning industry in general (Saengpassa, 2013).

Vicheanpanya (2014) divides the concerns of Thai institutions in regards to LMS adaptation into three categories basic, mid-tier, and high concerns. Basic concerns related to cost and the monitoring of the LMS. Mid-term concerns focused on the impact on students and faculty as well as the curriculum. High concerns included managing change and facilitating cooperation.

Asia-Pacific International University is a small private college in Thailand located outside of Bangkok in the province of Saraburi. There are approximately 1,000 students enrolled at the university. The learning context for e-learning is primarily blended at both the undergrad and 
Running Head: MOODLE USAGE CASE STUDY

graduate level. There are no fully online learning courses offered by APIU. Moodle is the current adopted LMS of the institution.

Despite the various challenges with cost and implementation, e-learning is becoming the norm in higher education. This implies that schools need insights into the use and activity of e-learning at campuses that have already adopted a LMS and implemented it. An investigation into an institution's use of an LMS will help to provide information into a phenomenon that is not well-studied in Thailand as few schools have made strives toward e-learning technology practice.

\section{Methodology}

\section{Sample}

Census sampling of Moodle use was conducted at APIU. All activity that took place on Moodle at APIU from August 2016 to May of 2017 was included in this study for analysis. There was no distinction made in terms of faculty vs. student, gender, class, or major, as the Moodle logs do not provide this information.

\section{Research Design \& Instrument}

Data collection was longitudinal and collected by the Moodle server over the 2016-17 academic school year. Moodle usage was measured three ways, by activity rate, by user rate, and memory usage.

Activity rate was calculated by the number of request may to the server over a period of time such as month, day, hour or minute. By request, it is meant the clicking of the mouse by the user to inform Moodle to perform an action. 
Running Head: MOODLE USAGE CASE STUDY

User rate is the unique number of users over a given time period. One user can generate several requests such as a student clicking on a forum, then clicking on a quiz, and finally clicking to submit an assignment. The number of users was calculated over several different time periods. The user rate can also be divided by the total number of users to determine the percentage of activity Moodle users at the campus.

Memory usage is determined by the number of concurrent users. By concurrent users, it is meant the number of activities that are being requested of Moodle simultaneously (Moodle Docs, 2012). For example, if ten users are logged in to Moodle and five of them are clicking on items in Moodle and making request at the same moment it means there are 10 users but 5 concurrent users. For each gigabyte of memory, Moodle can support 50 concurrent users (Moodle News, 2011). Therefore, by knowing how much memory an institution has set aside for Moodle and the number of concurrent users per second it is possible to determine the percentage of memory being used at a given moment. Currently, APIU has set aside 6 GB of RAM, which can support up to 300 concurrent users.

\section{Data Collection}

Data was collected automatically through Moodle. The activity log compiled by Moodle was downloaded and analyzed.

\section{Data Analysis}

Analysis was primarily descriptive and involved the calculation of means as well as the development of plots to track activities over time. Since the sampling was census and there was no desire to generalize, inferential statistics were not necessary, as the sample and the population were the same in this study. 
Running Head: MOODLE USAGE CASE STUDY

\section{Results}

Over the course of the $2016-17$ school year about 1.5 million $(1,525,591)$ clicks took place requesting action from the Moodle server. In all there were over $1,000(1,145)$ unique users of Moodle at APIU. By semester there was over $800,000(817,308)$ clicks during $1^{\text {st }}$ semester and over 700,000 clicks during $2^{\text {nd }}$ semester, which represents a $13 \%$ decline in use from $1^{\text {st }}$ to $2^{\text {nd }}$ semester. Plot 1 is a plot of Moodle use by semester.

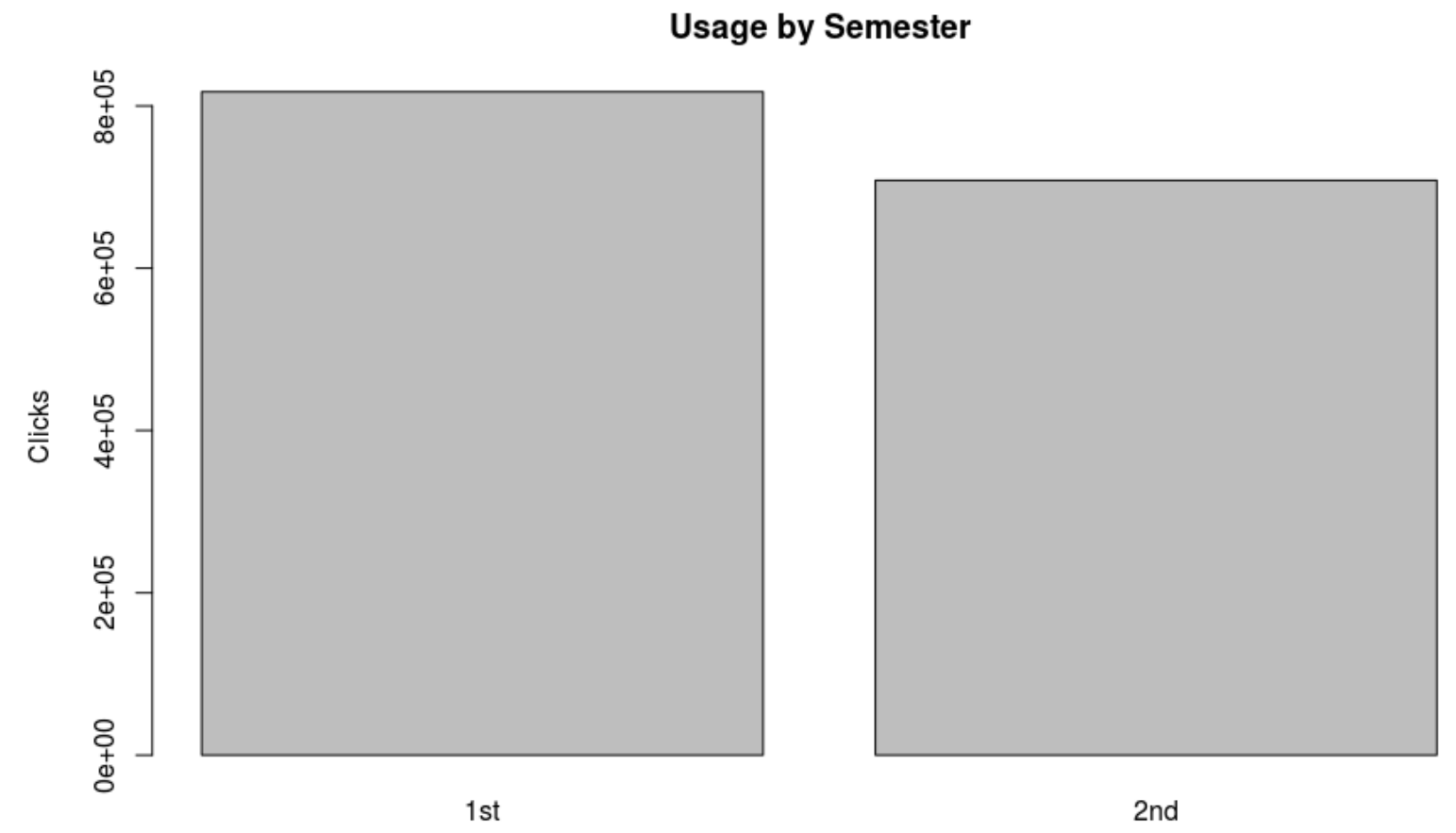

Plot 1: Usage by semester

\section{Monthly Stats}

In terms of usage by month, there was about $150,000(152,55.91)$ clicks per month for the ten months that comprise the $1^{\text {st }}$ and $2^{\text {nd }}$ semester (August-May). For $1^{\text {st }}$ semester, the highest usage month is September with a steady decline afterwards. For $2^{\text {nd }}$ semester, the trend is slightly different with usage grow each month until March and then declining fast after 
this. The months of August, December, and May are all partial months in the academic calendar with significant time lost for holidays. Plot 2 shows the usage by month.

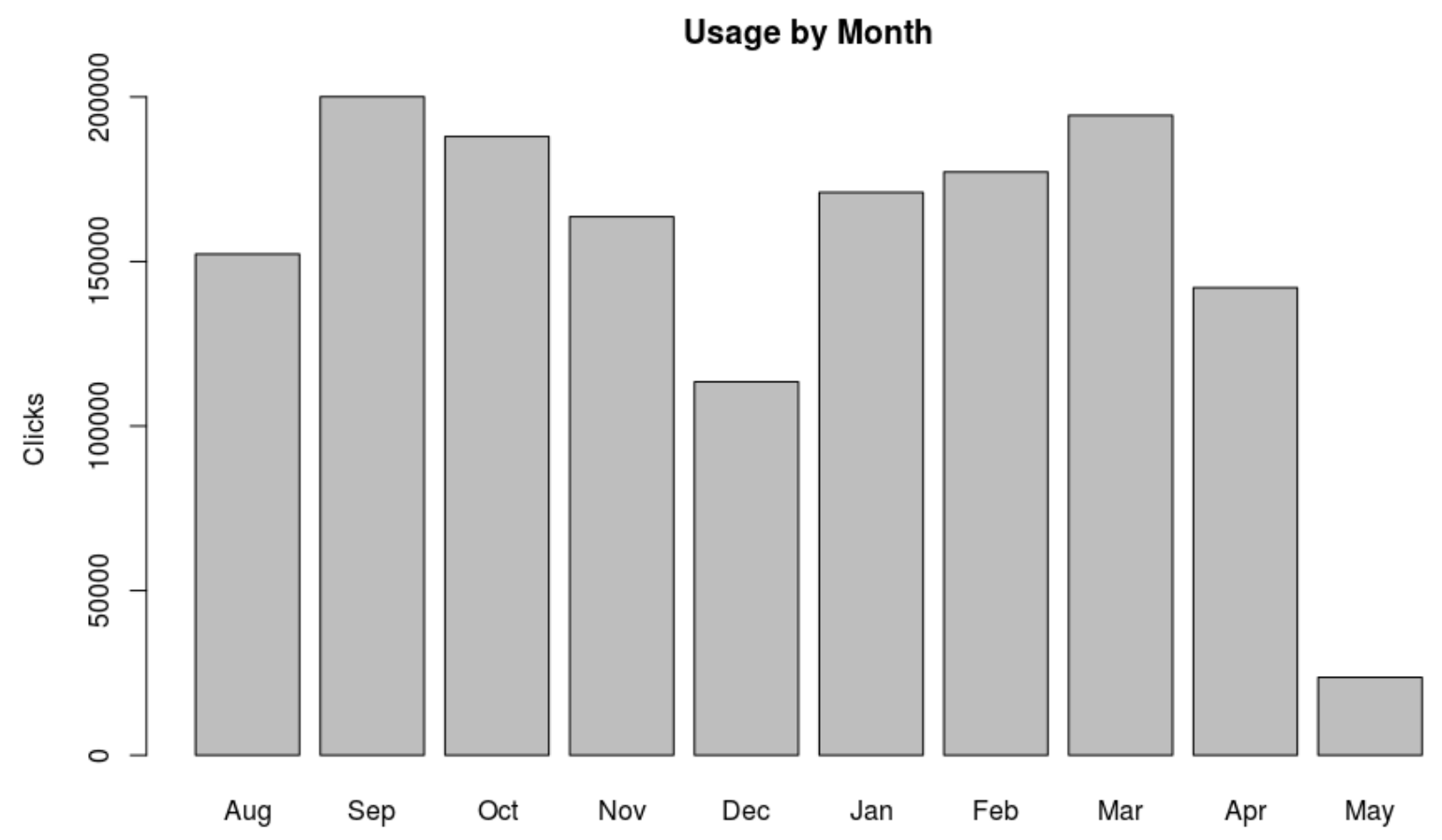

Plot 2: Usage by month

\section{Daily Stats}

Usage by day was over $5,000(5,085)$ clicks. For usage by hour, the average number of clicks was over 200 (211). For usage by hour, this number was summed over the course of the year to determine Moodle use over the year in a day. At APIU, Moodle use is at its peak at $10 \mathrm{am}$ with a decline at $12 \mathrm{pm}$ followed by another peak at $3 \mathrm{pm}$. From $3 \mathrm{pm}$ to $6 \mathrm{pm}$, there is a steady decline with an increase starting at $6 \mathrm{pm}$ and continuing until $9 \mathrm{pm}$. From $9 \mathrm{pm}$, there is a gradual decline until 6am of the following day. Plot 3 shows usage per hour. 
Running Head: MOODLE USAGE CASE STUDY

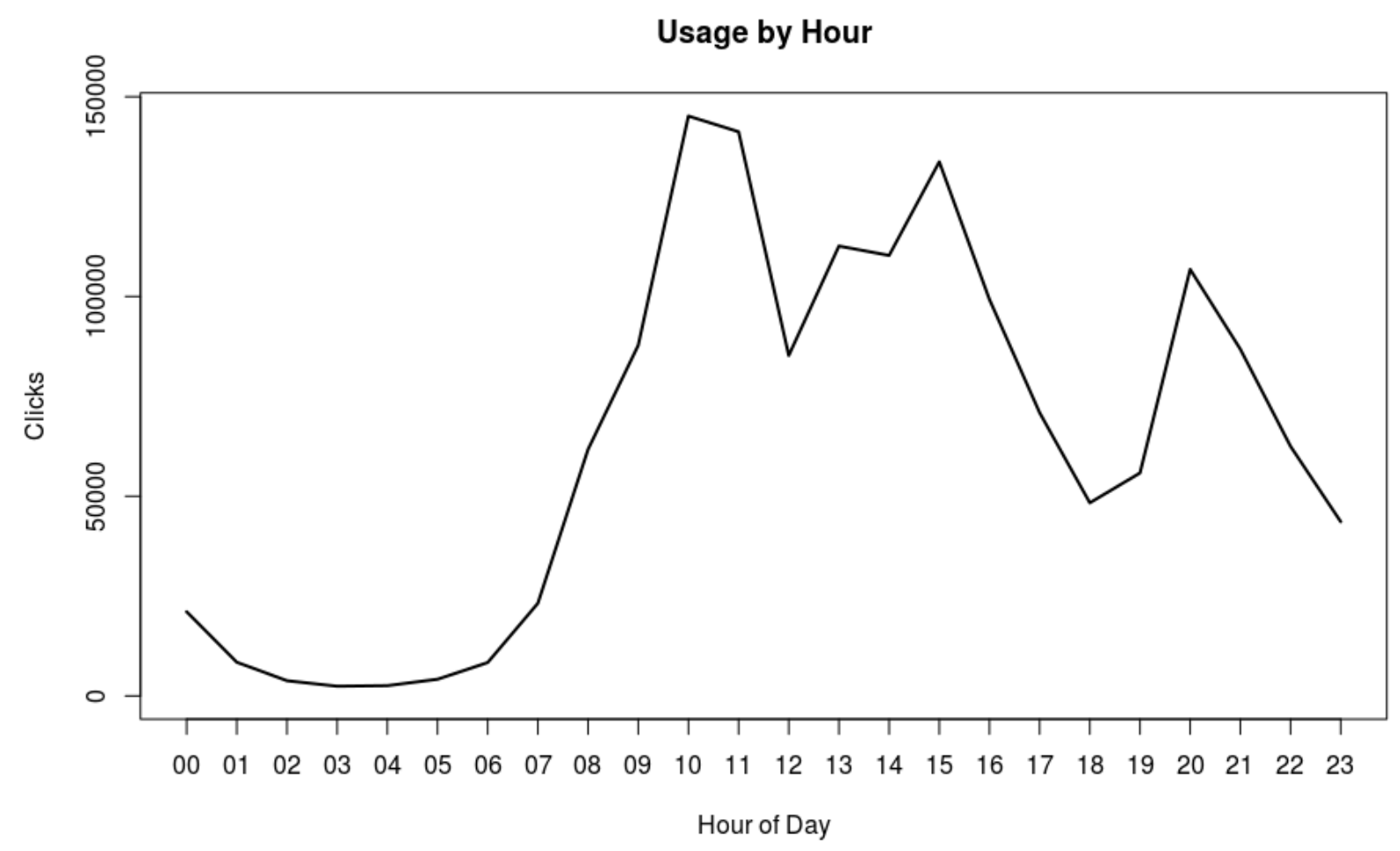

Plot 3: Usage by hour

The usage rate in terms of the overall use of memory set aside for Moodle at APIU was also calculated. This chart shows the clicks per second of a given hour during the year while considering the overall memory usage. Generally, memory usage rarely exceeds $20 \%$. Plot 4 shows the memory usage. 


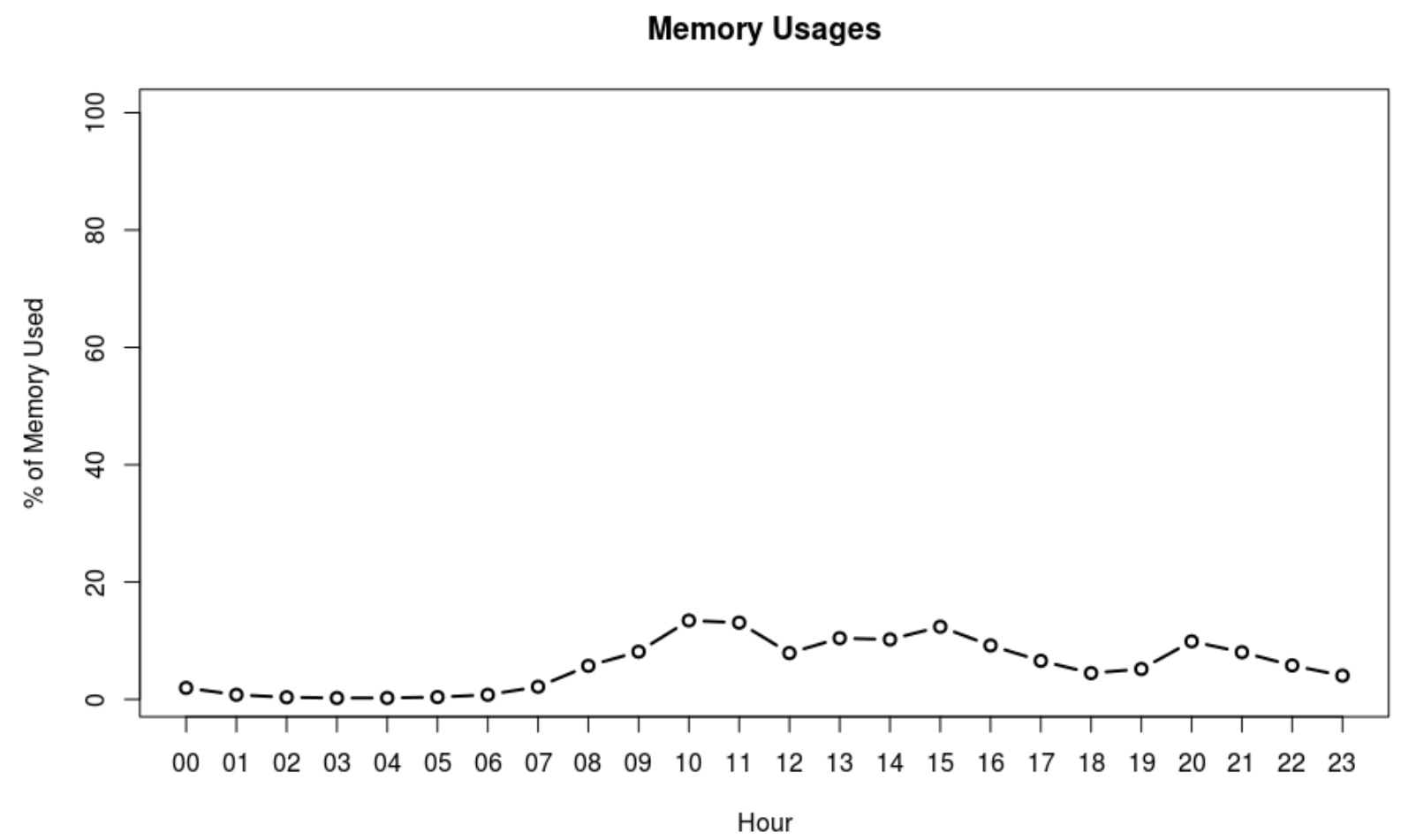

Plot 4: Memory usage per hour

\section{Activity Stats}

The most popular activities (excluding system, which means someone has logged in) used in Moodle were quiz and assignment. After these two activities, there is a steep drop-off with forum, file, and file submission coming next. User report is the default view when checking grades as faculty or as a student. All together, the use of quizzes and assignments activities accounts for $63 \%$ of Moodle activity among users at APIU. Some of the least popular activities include database, chat, choice, wiki, and lesson. Plot 5, provides a graph of the most popular activities used in Moodle at APIU. 


\section{Most Popular Activities}

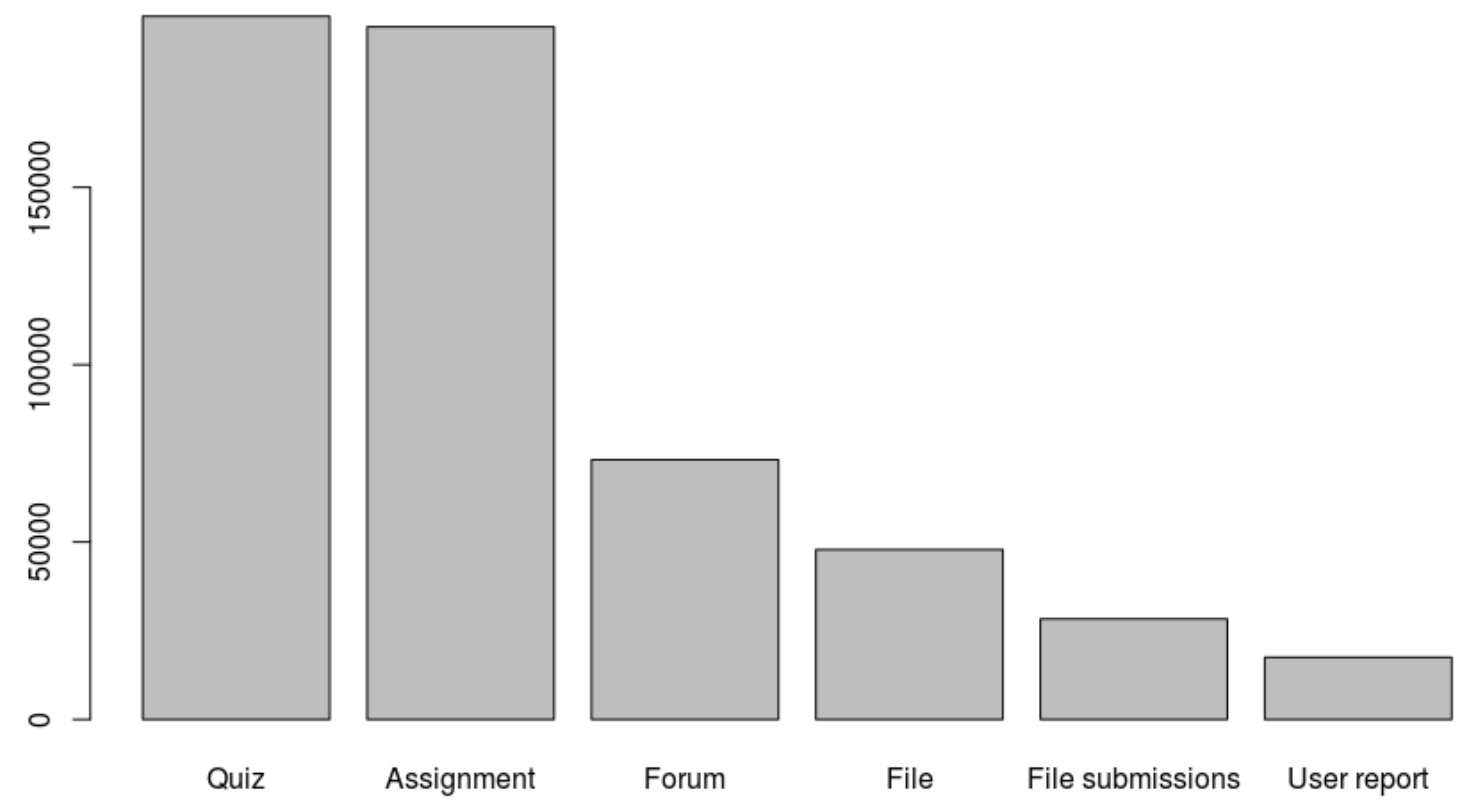

Plot 5: Most popular activities

The rate per hour of the most popular activities was also plotted. The most popular activity is quiz and the most popular hour for quizzes is $4 \mathrm{pm}$. Assignment submission peaks before lunch (11am), dinnertime $(4 \mathrm{pm})$, and late evenings (9pm). The other activities maintain a steady usage rate throughout the day. Plot 6 shows the act ivies by hour 


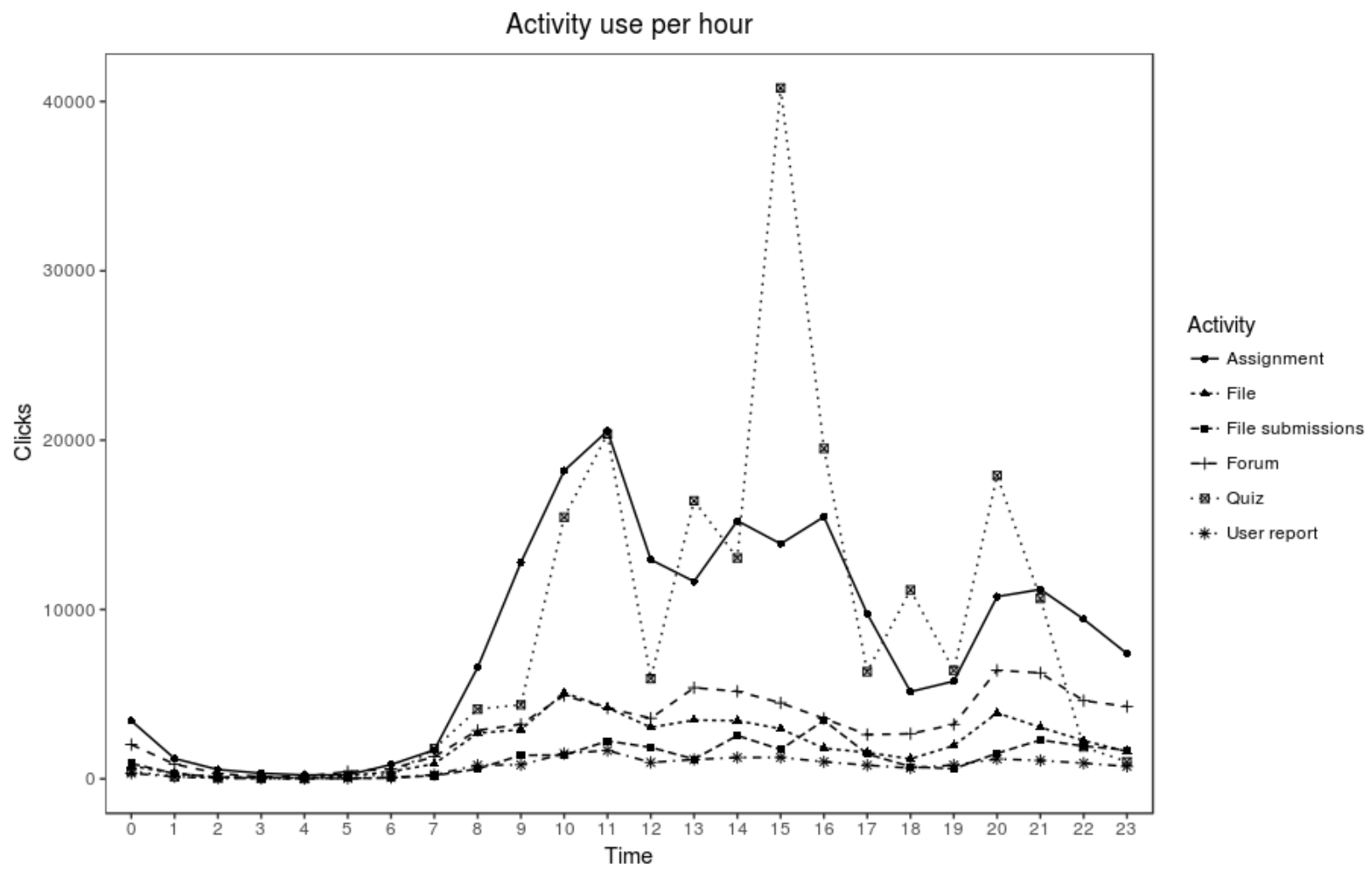

Plot 6: Activity use per hour

Of the over $1,100(1,145)$ users of Moodle at APIU, the average number of clicks per user for the year was about $1,300(1,332)$. This breaks down to approximately $700(666)$ clicks per semester, 130 (133) clicks per month or 4 clicks per day. In general, Moodle usage is low when considering clicks per user. Fifty percent of the Moodle usage happened among the top $10 \%$ of users.

\section{Discussion and Conclusion}

This study has led to several major findings. One, Moodle use at APIU shows a clear pattern. The drop from first to second semester is probably due to the newest of the Moodle learning experience wearing off for both faculty and students. Another reason may be that users' perception of the usefulness and ease of use changed (Davis, Bagozzi, \& Warshaw, 1989). 
Running Head: MOODLE USAGE CASE STUDY

In addition, there is normally a small decline in enrollment from first to second semester as students graduate, dropout, or transfer in the middle of the school year.

Two, Moodle use is primarily limited to two activities, which are quiz and assignments. Given the huge number of plugins and standard modules that come with the standard Moodle version, this is a narrow use of a learning management system. This may further indicate challenges with the technical aspects of Moodle as users do not seem to make any efforts to expand into less familiar online learning experiences (Sanchez \& Hueros, 2010).

Three, the current resources committed to Moodle at APIU seem to be adequate when considering memory. Adequate memory is considered one of the best ways to enhance the performance of Moodle (Moodle.org, 2016). Given the number of users at APIU, it is probably not necessary to increase memory size unless there is an unforeseen step forward in technology.

This study leads to the following recommendations. One, there is a need to provide further training in the use of quizzes as they are the most popular activity in terms of what is used at APIU. There are a whole host of features that can be used to tap into the potential of quizzes. Examples include, calculated questions, essays, short answer, the use of audio and video during a quiz, time limits, shuffled answers, shuffled question, are just some of the features that faculty may be unaware of.

Two, it may be valuable to provide training in some of the unpopular activities. There are over 20 unique activities in the standard Moodle version. Expanding faculty knowledge in terms of how to use books, glossary, attendance, wiki, and choice will allow them to provide an enhance learning experience for their students. Diverse learning experience whether online or 
Running Head: MOODLE USAGE CASE STUDY

in a blended context can help in retention of what is learned as well as the application of it (Borich, 2011; Brown, 2004).

Three, Moodle use is low overall and in terms of the distribution of users. This indicates that implementation needs to be address. As such, the institution should considered developing a clear plan of implementation with goals and measureable objectives that can be used to track faculty development in the use of Moodle (Ornstein \& Hunkins, 2009).

In terms of further studies, it would be useful to find the perceptions of students and teachers towards Moodle. In addition, study the specific use of various instructional design models for e-learning would help to determine what ways of teaching are most appropriate for students in the context of this study. Lastly, exploring data such as this over several years can help in identifying trends in Moodle use at APIU.

This study is limited to the context of APIU. The results are not generalizable. However, the results of this study can be used for comparison purposes for other schools with similar characteristics. Furthermore, the Moodle logs were limited in the data that they collect. Understanding additional demographic variables was not possible.

This study provided a glimpse into the actual use of Moodle at APIU. There is room for continued growth with the given technological limits of the university. However, growth is will primarily happen through expanding knowledge of Moodle to empower teacher to use more of the available features within Moodle. 


\section{References}

Al-Qahtani, A., \& Higgins, S. (2012). Effects of traditional, blended and e-learning on students' achievement in higher education. Journal of Computer Assisted Learning, 29(3), 220234.

Banditvilai, C. (2016). Enhancing students' language skills through blended learning. The Electronic Journal of e-Learning, 14(3), 220-229.

Bernard, R., Borokhovski, E., Schmid, R., Tamim, R., \& Abrami, P. (2014). A meta-analysis of blended learning and technology use in higher education: From the general to the applied. Journal of Computing in Higher Education, 26(1), 87-122.

Borich, G. (2011). Effective teaching methods: Researched-Based practice (7th ed.). Boston, MA: Pearson.

Brown, H. (2004). Language assessment: Principles and classroom practices. London, UK: Longman.

Bruff, D., Fisher, D., McEwen, K., \& Smith, B. (2013). Wrapping a MOOC: Student perceptions of an experiment in blended learning. MERLOT Journal of Online Learning and Teaching, 9(2), 187-200.

Capterra. (2015, April 8). LMS Industry User Research Report. Retrieved September 6, 2016, from Capterra: http://www.capterra.com/learning-management-system-software/userresearch

Davis, F., Bagozzi, R., \& Warshaw, P. (1989). User acceptance of computer technology: A comparision of two theoretical models. Management Science, 35(8), 982-1003.

Docebo. (2014). E-Learning market trends \& forecast 2014 - 2016 report. Athens, GA: Docebo. Edutechnica. (2014, May 26). LMSs by the Numbers - Spring 2014 Updates. Retrieved April 28, 2017, from Edutechnica: http://edutechnica.com/2014/05/26/lms-by-the-numbers-spring2014-updates/

Edutechnica. (2015, March 8). LMS data - Spring 2015 updates. Retrieved September 6, 2016, from Edutechnica: http:/edutechnica.com/2015/03/08/lms-data-spring-2015-updates/

Ellis, R. (2008). A field guide to learning management systems. Alexandria, VA: ASTD.

Gaya, J. (2013, Janurary 21). Pros and Cons of E-learning. Retrieved September 6, 2016, from Elearning Industry: https://elearningindustry.com/pros-and-cons-of-campus-learning-vsonline-learning

Gogos, R. (2014, February 19). Why elearning is better. Retrieved September 6, 2016, from Elearning Industry: https://elearningindustry.com/why-blended-learning-is-better

Huang, X., \& Peng, Y. (2011). A development method of resources for e-learning based VRML. In Y. Wang (Ed.), Education Management, Education Theory and Education Application (pp. 865-872). India: Springer.

Mala, D. (2016, September 5). Education needs 'digital-age' boost. Bangkok Post.

Means, B., Toyama, Y., Murphy, R., \& Baki, M. (2013). The effectiveness of online and blended learning: A meta-analysis of the empirical literature. Teacher College Record, 115, 1-47.

Moodle Docs. (2012, June 3). Performance FAQ. Retrieved September 5, 2016, from Moodle Docs:

https://docs.moodle.org/22/en/Performance_FAQ\#How_do_you_define_.22concurrent_u sers. $22.3 \mathrm{~F}$

Moodle News. (2011, March 9). Doc of the Day: Calculating required RAM per student.

Retrieved September 5, 2016, from Moodle News:

http://www.moodlenews.com/2011/doc-of-the-day-calculating-required-ram-per-student/ 
Moodle.org. (2016, April 8). Performance Recommendations. Retrieved May 8, 2017, from Moodle: https://docs.moodle.org/23/en/Performance_recommendations

Ornstein, A., \& Hunkins, F. (2009). Curriculum: Foundations, principles, and issues. Boston, MA: Pearson.

Pappas, C. (2015, October 13). Blended Learning Advantages And Disadvantages In Corporate Training. Retrieved September 6, 2016, from E-learning Industry:

https://elearningindustry.com/blended-learning-advantages-and-disadvantages-incorporate-training

Peters, D. (2014). Interface design for learning: Design strategies for learning experiences. San Franciso, CA: New Riders.

Saengpassa, C. (2013, December 2). E-Learning slow to progress in Thailand. The Nation.

Sanchez, R., \& Hueros, A. (2010). Motivational factors that influence the acceptance of Moodle using TAM. Computers in Human Behavior, 26(6), 1632-1640.

Staker, H., \& Horn, M. (2012). Classifying K-12 blended Learning. Boston, MA: Innosight.

Stantchev, V., Colomo-Palacios, R., Soto-Acosta, P., \& Misra, S. (2014). Learning management systems and cloud file hosting services: A study on students' acceptance. Computers in Human Behavior, 31, 612-619.

Suanpang, P., \& Petocz, P. (2006). E-Learning in Thailand: An analysis and case study. International Journal on E-Learning, 5(3), 415-438.

Vicheanpanya, J. (2014). E-Learning management system model for Thai society . International Journal of Information and Education Technology, 4(1), 67-70.

Winstead, S. (2016, March 3). 6 Disadvantages of Blended Learning You Have to Cope With. Retrieved September 6, 2016, from My Elearning World:

https://myelearningworld.com/6-disadvantages-of-blended-learning/ 